ORIGINAL ARTICLE

\title{
Clinical effectiveness of rigid or kinesio taping and manual therapy on pain and function in patients with shoulder impingement syndrome
}

\author{
Saniye AYDOĞAN ARSLAN ${ }^{1}$, Fatih ERBAHÇECi² ${ }^{2}$,Elem YORULMAZ ${ }^{3}$, Gül BALTACI ${ }^{4}$
}

Purpose: The purpose of the study was to compare the effect of two taping techniques and manual therapy, applied in addition to the conventional physiotherapy program, on pain and function in patient with subacromial impingement syndrome.

Methods: A total of 55 patients participated in this study. Patients were divided into four groups; Kinesio taping group, McConnell taping group, manual therapy group, and control group. Conventional physiotherapy (5 days a week for four weeks) was applied to the patients in all groups. The level of pain was assessed by the Visual Analogue Scale, and the functional activity level was assessed by the Disabilities of the Arm, Shoulder, and Hand-DASH Questionnaire. The patients were assessed before treatment and after treatment.

Results: There was a significant difference in terms of pain severity and functional activity levels after treatment when compared to the pre-treatment period in all groups $(p<0.05)$. When the treatment groups were compared with the control group, a significant difference was observed in terms of pain severity and functional activity levels after treatment when compared to the pre-treatment period $(p<0.05)$. However, when the treatment groups were compared with each other, it was observed that there was no difference in terms of changes in pain severity and functional activity levels after treatment when compared to the pretreatment period $(\mathrm{p}>0.05)$.

Conclusions: There was a significantly greater decrease in pain intensity after all three applications than the control group. It was observed that they did not have significant superiorities over one another in terms of pain and functionality parameters. Keywords: Shoulder impingement syndrome, athletic tape, musculoskeletal manipulations.

\section{Omuz sıkışma sendromu olan hastalarda rijit veya kinezyo bantlamanın ve manuel terapinin} ağrı ve fonksiyon üzerine klinik etkisi

Amaç: Çalışmanın amacı, subakromiyal sıkışma sendromu hastalarında geleneksel fizyoterapi programına ek olarak uygulanan iki bantlama tekniği ve manuel terapinin ağıı ve fonksiyon üzerindeki etkisini karşılaştırmaktır.

Yöntem: Çalışmaya toplam 55 hasta katıldı. Hastalar dört gruba ayrıldı; Kinezyo bantlama grubu, McConnell bantlama grubu, manuel terapi grubu ve kontrol grubu. Tüm gruplardaki hastalara geleneksel fizyoterapi (4 hafta boyunca haftada 5 gün) uygulandı. Ağrı seviyesi Görsel Analog Skala ile ve fonksiyonel aktivite düzeyi Kol, Omuz ve El Sorunları AnketiDASH ile değerlendirildi. Hastalar tedaviden önce ve tedaviden sonra değerlendirildi.

Bulgular: Tedavi sonrası ağrı şiddeti ve fonksiyonel aktivite düzeyleri açısından tüm gruplarda tedavi öncesi döneme göre anlamlı farklııı gözlendi $(p<0,05)$. Tedavi grupları kontrol grubu ile karşılaştıııldığında tedavi öncesi döneme göre tedavi sonrası ağıı şiddeti ve fonksiyonel aktivite düzeyleri açısından anlamlı farklılık gözlendi $(p<0,05)$. Ancak tedavi grupları birbirleri ile karşılaştırıldığında tedavi öncesi döneme göre tedavi sonrası ağı şiddeti ve fonksiyonel aktivite düzeylerindeki değişiklikler açısından fark olmadığı saptandı ( $p>0.05)$.

Sonuç: Her üç uygulamadan sonra ağn şiddetinde kontrol grubuna göre anlamlı ölçüde daha fazla azalma oldu. Ağn ve ișlevsellik parametreleri açısından birbirlerine göre önemli üstünlükleri olmadığı görüldü.

Anahtar Kelimeler: Omuz sıkışma sendromu, atletik bant, Kas iskelet manipülasyonları.

\footnotetext{
1: Department of Physiotherapy and Rehabilitation, Kırıkkale University Faculty of Health Sciences, Kırkkale, Turkey.

2: Hacettepe University Faculty of Physiotherapy and Rehabilitation, Ankara, Turkey

3: Haydarpaşa Numune Education and Research Hospital, Department of Physical Medicine and Rehabilitation, istanbul, Turkey

4: Department of Physiotherapy and Rehabilitation, Private Güven Hospital, Ankara, Turkey

Corresponding Author: Saniye Aydoğan Arslan: fztsaniye1982@gmail.com

ORCID IDs (order of authors): 0000-0001-5470-9849; 0000-0002-7806-8166; 0000-0002-3036-7722; 0000-0002-6513-2499

Received: September 16, 2020. Accepted: Debember 8, 2020.

DOI: $10.15437 /$ jetr. 795293
} 
$\mathrm{S}$ ubacromial impingement syndrome (SIS) is the most common cause of shoulder complaints in individuals applying to orthopedic and physical therapy clinics (44$65 \%) .{ }^{1}$ Based on clinical findings and scientific experiments, a number of factors have been associated with the development of SIS. Researchers have attributed subacromial impingement to various factors, such as postural problems, dysfunction of force couples, flexibility deficits of the pectoralis minor and biceps that may especially affect the scapulohumeral rhythm, and as a result, due to a length-tension relationship impairment of the rotator cuff muscles, a deficit in the centralization of the humeral head into the glenoid cavity may occur. ${ }^{2}$

Taping has been recently considered as an option to control scapular movement in patients with shoulder problems. ${ }^{3}$ The function of the tape is to provide support during movement. ${ }^{4}$ The underlying mechanisms of taping effects are still unclear. It has been speculated that taping works by inducing proprioceptive feedback or providing alignment correction during dynamic movements. ${ }^{5}$

The Kinesio (KT) and McConnell (MC) taping techniques that aim to change the primary muscle activity are applied in accordance with different purposes on behalf of special techniques in the treatment of SIS. Although scientific studies on the mechanisms of action and efficiency of taping techniques are insufficient, the role of KT in the pain mechanism is attempted to be explained by different mechanisms, such as reducing edema and inflammation, the activation of the gate control mechanism by sensory stimuli and inhibitory mechanisms ensured by descending pathways, the analgesic effect by regulating superficial and deep fascia functions. ${ }^{6}$ Therefore, we think that it would be effective in resolving the glenohumeral joint inflammation and effusion since it aims to reduce edema and pain, increase the joint range of motion and muscle activity in patients. The mechanism of action of the MC technique is described as supporting a ligament, joint capsule, and inactive tissues, enhancing proprioception, taking the burden from painful tissues, providing biomechanical balance, inhibiting the excessive muscle activation, and facilitating weak muscles. ${ }^{7,8}$
The general aim of manual treatment is to provide restructuring, to accelerate the opening of adhesions, to provide painless function, and to increase the recovery capacity of the tissue, and to accelerate the return to the daily and/or sports life of the person. Although there are many studies in the literature on the effectiveness of manual therapy (MT) in the treatment of SIS ${ }^{9,10}$, there are very few studies investigating the effectiveness of $\mathrm{KT}$ and $\mathrm{MC}$ taping techniques in reducing pain, improving the function, and increasing the muscle strength. ${ }^{11,12}$ These studies have investigated acute period effects.

This study's goal was to investigate the effect of two taping techniques and manual therapy, applied in addition to the conventional physiotherapy program, on pain and function in SIS patients and to compare these techniques with each other. The hypothesis of our study is to reveal whether there is a difference between the groups in terms of pain and functionality.

\section{METHODS}

This study was carried out at the University, Department of Physiotherapy and Rehabilitation using a pre-test/post-test quasi experimental model with a control group. This study was approved by the Non-Interventional Research Ethics Committee of Hacettepe University (Meeting date: 26.07.2012; decision no: LUT 12/89-33), and all the participants gave written informed consent. Fifty-five patients, who were referred to a physiotherapy clinic, were aged between 25 and 55 years, had unilateral shoulder pain for more than four weeks, who consulted an orthopedic surgeon for Grade 1 or 2 subacromial impingement syndrome according to an MRI/Ultrasound assessment and clinical examination, had at least two positive tests (Neer painful arc, Hawkins-Kennedy), were enrolled in this trial. Patients with a history of shoulder surgery, fracture or dislocation, degenerative joint disorder of the shoulder complex, cervical radiculopathy, a steroid injection into or around the shoulder in the previous one year, and physical therapy during the last 12 months were excluded from the study. Patients with recurrent complaints or a long history of complaints over a year were also excluded from 
the study. Furthermore, MRI scans were assessed before they were involved in the trial. We analyzed the number of patients according to pain levels during an activity using $\mathrm{G}$ power. The G*Power program (version 3.0.10 Universität Düsseldorf, Düsseldorf, Germany) was used for post-hoc power analysis. In the post-hoc power analysis, when the statistical significance of alpha was $5 \%$ and the confidence interval was taken as $95 \%$, the power (1-B) of the study was found to be $99 \%$. The primary outcome was determined as Visual Analogue Scale (VAS). The details of the subject numbers included in and excluded from the study through final data analysis were provided as a flowchart in Figure 1.

The general descriptive characteristics of the cases with SIS diagnosis included in the present study were recorded. Shoulder, neck, and thoracic region posture disorders were evaluated by observational posture analysis in the anterior, posterior, and lateral directions.

The level of pain was assessed by the VAS during rest, activity, and at night, and the functional activity level was assessed by the Disabilities of the Arm, Shoulder, and Hand (DASH Questionnaire).8

After the patients were separated according to the specified exclusion and inclusion criteria, four groups were obtained using the online random allocation software program (KT, MC, MT, and control groups). The patients were included in the groups determined using the program at the time of arrival. The study was conducted five days a week in 5 sessions for four weeks. As a treatment program, together with conventional physiotherapy, KT was applied to the first group, MC taping to the second group, and manual therapy was applied to the third group.

Control group received only conventional physiotherapy. Ice application for $15 \mathrm{~min}$, pulsed ultrasound (Chattanooga Intelect Legend Ultrasound, Chattanooga, TN, USA; 1 $\mathrm{MHz}, 1$ watt/cm 2 , pulsed 1:2) for $5 \mathrm{~min}$, conventional Transcutaneous Electrical Nerve Stimulation TENS (TENS; Intelect Legend Stim, Chattanooga Group Inc., Hixson, TN, USA, $50 \mathrm{~Hz}, 60 \mu \mathrm{s}$ ) for $20 \mathrm{~min}$, and the same exercise program (20 min) were applied to all the four groups as a conventional physiotherapy program. All treatments were performed by the same physiotherapist, while evaluations were made by the other author.

Exercise Therapy: The exercise therapy included 3 phases, and each phase consisted of strengthening/muscle re-education exercises for the scapula stabilizers and the rotator cuff in addition to flexibility exercises. Flexibility exercises were composed of the posterior capsule with "cross-body stretch," upper thoracic extension stretch, and active range of motion stretching for the glenohumeral joint for flexion and abduction. They were held in 3 repetitions of 30 seconds each. Codman's pendulum exercises were also added to the program for improvement of the range of motion in a pain-free range. After flexibility exercises, strengthening exercises were conducted according to the phase of exercise. Strengthening exercises were performed in 3 sets of 10 repetitions, using a $150^{-} \mathrm{cm}$ long precut section of Thera-Band (Hygenic Corporation, Akron, OH). The participants began exercising using the no-latex yellow band at mild tension, and when they were able to perform three sets of 15 repetitions without significant pain or fatigue, they progressed to the next color resistive band in the sequence: red, green, and blue. Phase 1 emphasized the strengthening of the rotator cuff with the avoidance of excessive upper trapezius activity and serratus strengthening. Shoulder elevation exercises were added in phase 2 , and in phase 3 , the subject was instructed to continue the exercises from phase 2 in addition to new exercises, such as push-up on wall and push-up plus with Thera-Band. The exercise prescription and loading continued every week during the treatment session. An exercise booklet designed for the study regarding literature recommendations was given to each participant in order to standardize the exercise regimen and to facilitate the task of the participant. The participants were also encouraged to do their exercises at home regularly and were checked for continuity.

Manual Therapy: The MT group received a combination of manual therapy techniques applied by the therapist. General mobilization, including superoinferior gliding, rotations, and distractions to the scapula, was applied 3 to 5 times. Scapulothoracic joint mobilization techniques (Figure 2a) and mobilization techniques for the glenohumeral joint were applied according to the patient's needs as MT 
(glenohumeral longitudinal distraction and GH joint long axis traction, elevated shoulder stretching, relaxation under traction and glenohumeral lateral distraction techniques) (Figure 2b). Glenohumeral joint mobilization with long-axis traction and posterior or inferior glide techniques to improve shoulder internal rotation limitations were applied according to the individual requirements of the participants. ${ }^{13}$ Manual therapy was applied every other day.

\section{Kinesio Taping}

The KT inhibition muscle technique was applied to the supraspinatus and deltoid muscles with the $\mathrm{Y}$ tape with a $10 \%$ stretch from distal to proximal (Figure 3a). First, the muscle technique was applied to the specifically affected muscle with no tension on the band with a Y shape. Afterward, the Kinesio taping mechanical correction technique was applied for the glenohumeral joint. The mechanical correction was performed in the form of I band with 50-75\% tension, in the position of retraction, depression of the scapula, and external rotation of the humeral head. ${ }^{14}$ All techniques were identified according to the tissue that was in need of help. The taping assessment protocol was standardized through the education of the physiotherapist involved in the study by the Kinesio Taping University. A standard 2-in $(5-\mathrm{cm})$ Kinesio Tex tape was applied every day after the treatment.

McConnell Taping: The supraspinatus and the shoulder McConnell humerus head relaxation techniques were applied. The purpose of the shoulder McConnell humerus head relocation technique is to lift the humerus head upward anteriorly and backward and to increase the area between the acromion and the elevated humerus. The tape should not be applied in a very tense way in the anterior part. Since this area is very sensitive, it can irritate the skin (Figure $3 \mathrm{~b}$ ). The McConnell taping methods were repeated every day after the treatment. ${ }^{15}$

\section{Statistical analysis}

The SPSS for Windows version 22 was used for statistical analysis (SPSS Inc. Chicago, Illinois, USA). The statistical level of significance was defined as $\mathrm{p}<0.05$. The normality of data distribution was assessed by the Shapiro-Wilk test. The multi-eyed chisquare test was used to analyze differences between the groups of qualitative data. Kruskal-Wallis Variance Analysis was used to analyze differences between the groups of quantitative data. The Wilcoxon signed-rank test was used for the intra-group evaluations of the findings obtained. The Mann-Whitney U test was used to compare the findings of both groups.

\section{RESULTS}

Comparison of demographic profile showed that most of the patients suffering from SIS were female in all groups. Sociodemographic data, regular exercise habits, posture analysis results according to the groups are presented in Table 1.

There was no statistically significant difference between the groups in terms of severity of the pain experienced during rest, activity, at night and the functional activity level before treatment $(p>0.05)$.

It was determined in the evaluations performed in all four groups that pain decreased in terms of changes occurring in the pain severity experienced by the cases during rest, activity, at night, and functional activity levels $(\mathrm{p}<0.05)$ (Table 2). When the treatment groups were compared with the control group, a significant difference was observed in terms of pain severity and functional activity levels after treatment when compared to the pre-treatment period $(p<0.05)$ (Figure 4). However, when the treatment groups were compared with each other, it was observed that there was no difference in terms of changes in pain severity and functional activity levels after treatment when compared to the pre-treatment period $(p>0.05)$ (Table 3).

\section{DISCUSSION}

To our knowledge, this is the first study to compare two different taping and manual therapy in primary care patients presenting with SIS signs and symptoms compared to conventional physical therapy alone. There was a significantly greater decrease in pain intensity after all three applications than the control group. It was observed that they did not have significant superiorities over one another 


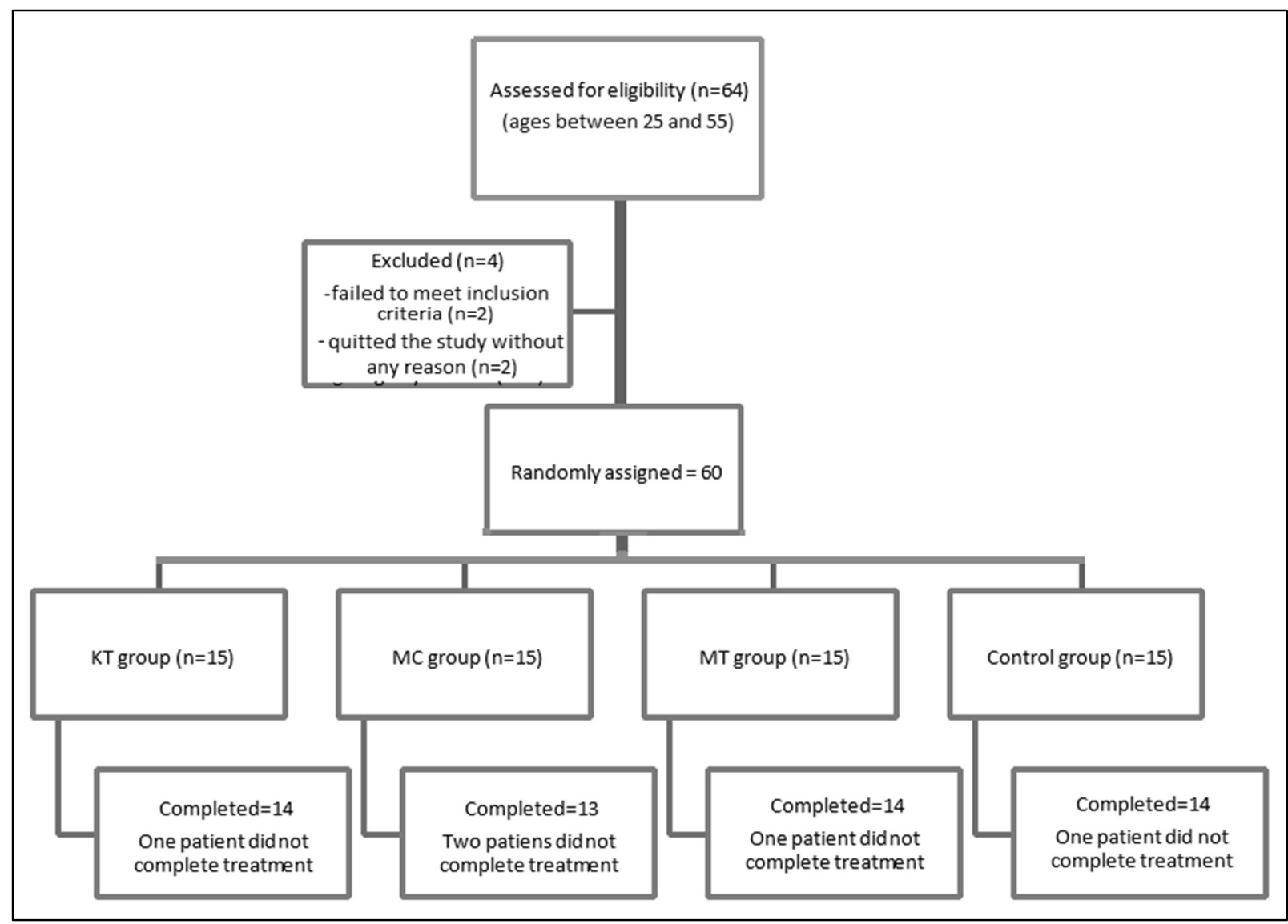

Figure 1: Flow chart.

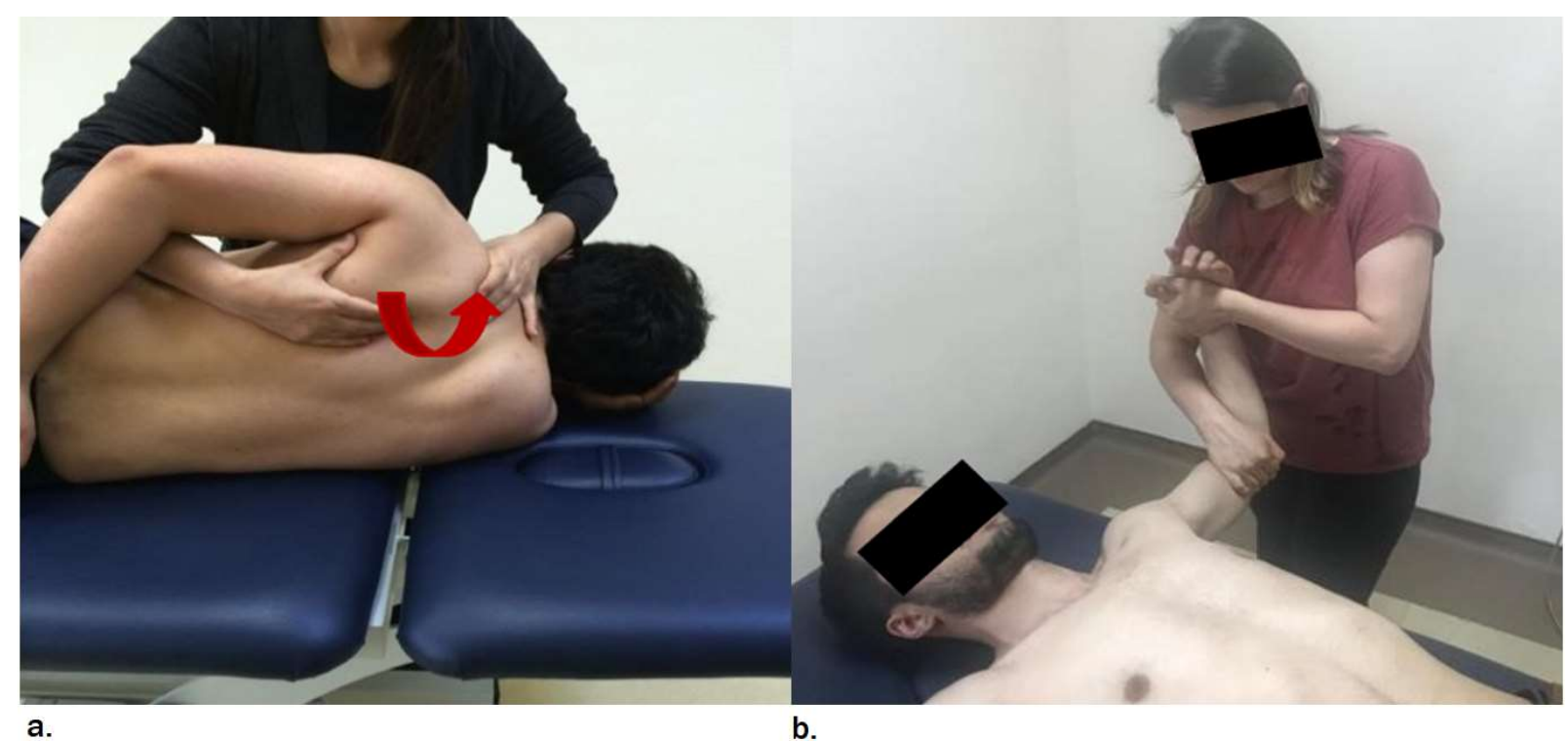

Figure 2: a. Scapulothoracic joint mobilization techniques, b. Glenohumeral lateral distraction techniques. 


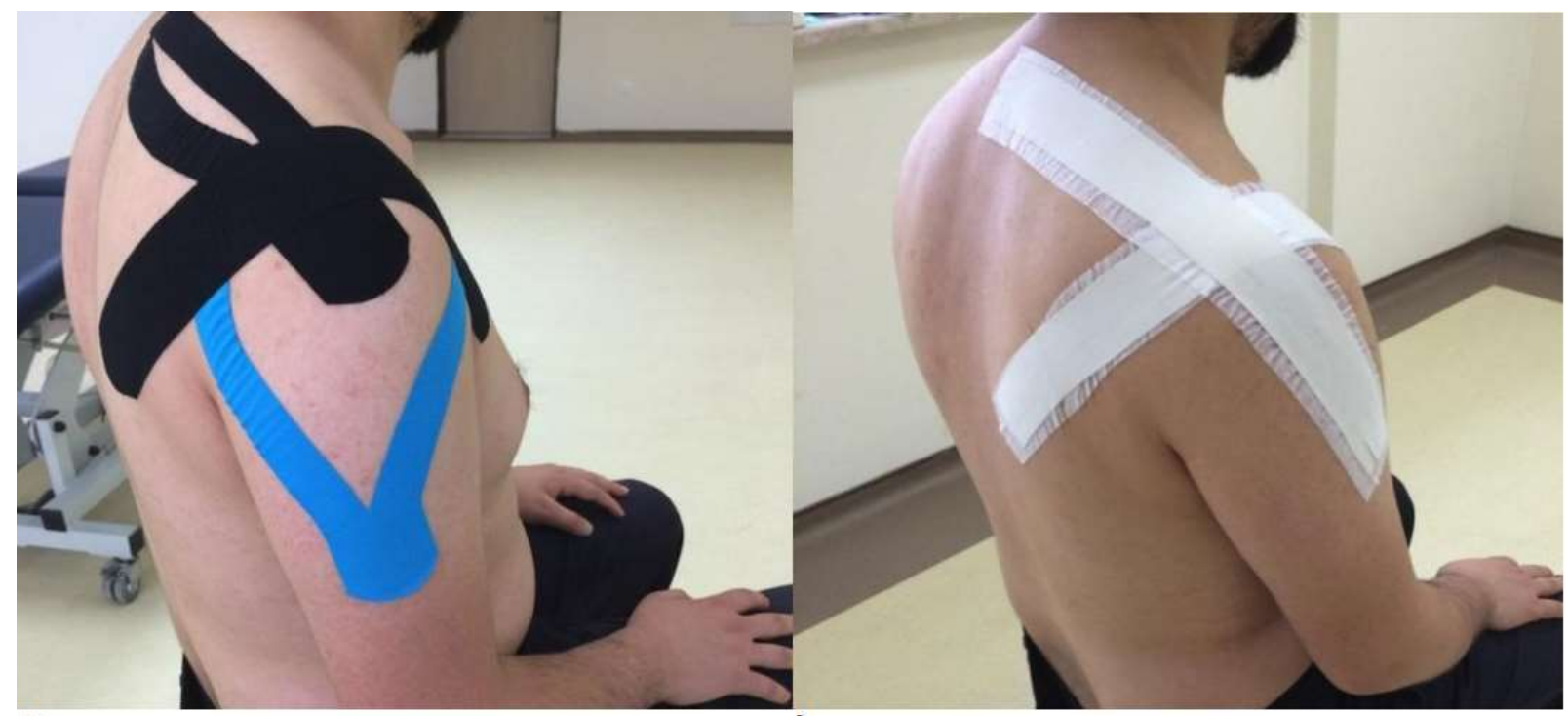

a.

b.

Figure 3: a. Supraspinatus, deltoid muscles and glenohumeral joint mechanical correction techniques; $b$. The shoulder McConnell humerus head relaxation technique and the Supraspinatus McConnell taping technique.

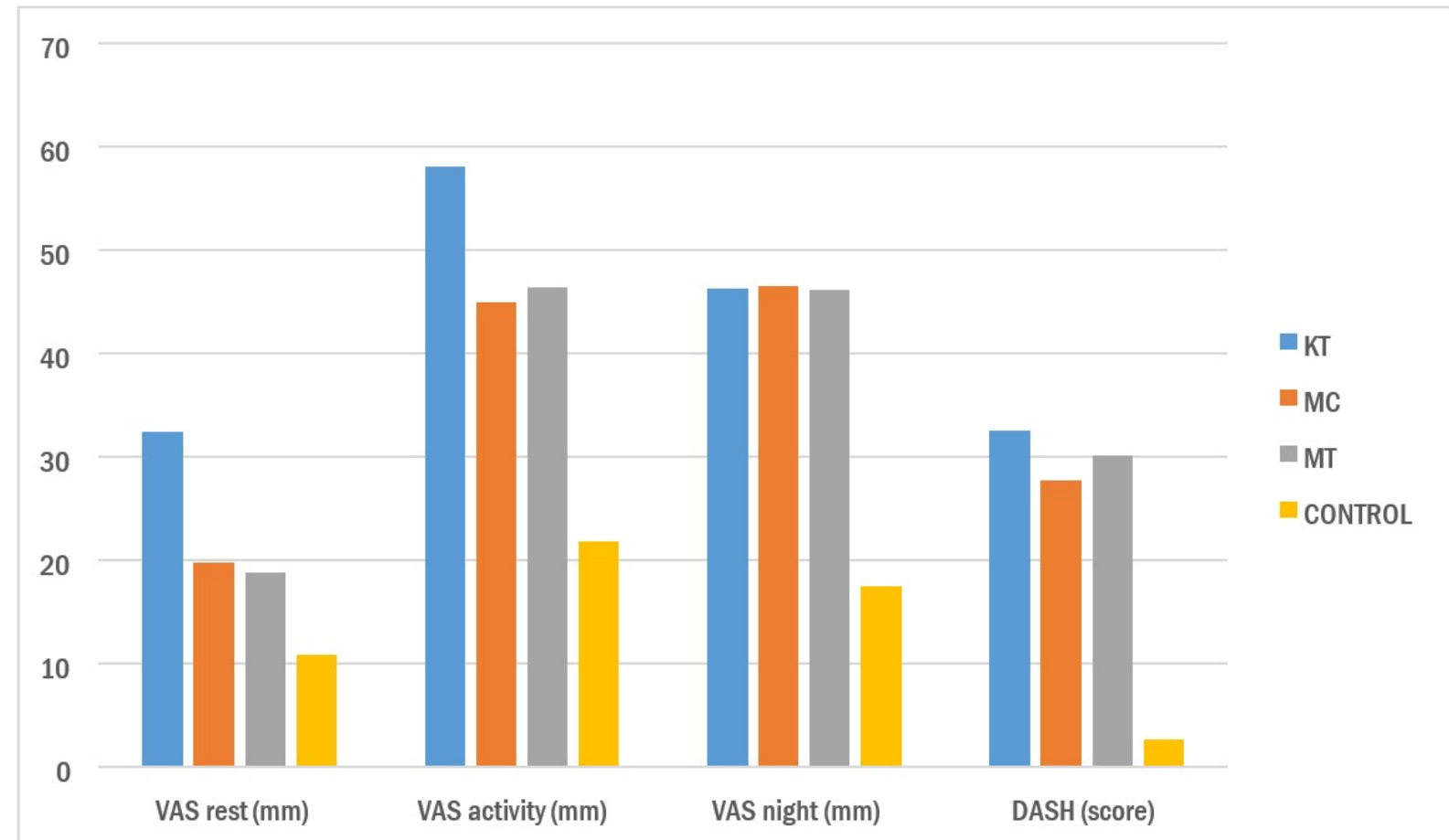

Figure 4: Comparison of the changes in the pain and functional activity levels after the treatment between treatment groups and control group. 
Table 1: Demographic data of the groups.

\begin{tabular}{lccccc}
\hline & $\mathrm{KT}$ & $\mathrm{MC}$ & $\mathrm{MT}$ & Control & $\mathrm{p}$ \\
& $\mathrm{X} \pm \mathrm{SD}$ & $\mathrm{X} \pm \mathrm{SD}$ & $\mathrm{X} \pm \mathrm{SD}$ & $\mathrm{X} \pm \mathrm{SD}$ & \\
\hline Age, mean (year) & $49.42 \pm 6.52$ & $50.38 \pm 5.78$ & $50.57 \pm 6.67$ & $47.92 \pm 6.76$ & 0.630 \\
Body mass index $\left(\mathrm{kg} / \mathrm{m}^{2}\right)$ & $33.27 \pm 6.46$ & $27.95 \pm 2.04$ & $28.57 \pm 6.67$ & $29.67 \pm 5.86$ & 0.140 \\
\hline \multicolumn{7}{l}{} & $\mathrm{n}(\%)$ & $\mathrm{n}(\%)$ & $\mathrm{n}(\%)$ & $\mathrm{n}(\%)$ & \\
\hline Gender & & & & \\
$\quad$ Female & $12(85.7)$ & $9(69.2)$ & $9(64.3)$ & $8(57.1)$ & 0.407 \\
$\quad$ Male & $2(14.3)$ & $4(30.8)$ & $5(35.7)$ & $6(42.9)$ & \\
Hand dominance & & & & $13(92.9)$ & 0.572 \\
$\quad$ Right & $14(100)$ & $13(100)$ & $13(92.9)$ & $1(7.1)$ & \\
$\quad$ Left & $0(0)$ & $0(0)$ & $1(7.1)$ & & \\
Affected side & & & & \\
$\quad$ Right & $6(42.9)$ & $6(46.2)$ & $10(71.4)$ & $7(50.0)$ & 0.427 \\
$\quad$ Left & $8(57.1)$ & $7(53.8)$ & $4(28.6)$ & $7(50.0)$ & \\
Regular exercise habits & $3(21.4)$ & $2(15.4)$ & $3(21.4)$ & $2(14.3)$ & 0.772 \\
Rounded shoulder & $7(50)$ & $7(53.8)$ & $6(42.9)$ & $5(35.7)$ & 0.787 \\
Kyphosis & $2(14.3)$ & $2(15.4)$ & $3(21.4)$ & $3(21.4)$ & 0.938 \\
\hline
\end{tabular}

KT: Kinesio Taping Group. MC: McConnell Taping Group. MT: Manual Therapy Group.

Table 2: Results of the pain and functional activity levels of the groups.

\begin{tabular}{|c|c|c|c|}
\hline & $\begin{array}{c}\text { Pre } \\
\mathrm{X} \pm \mathrm{SD}\end{array}$ & $\begin{array}{l}\text { Post } \\
\mathrm{X} \pm \mathrm{SD}\end{array}$ & $\mathrm{p}$ \\
\hline \multicolumn{4}{|l|}{ Kinesio Taping Group } \\
\hline VAS-rest (mm) & $49.71 \pm 26.19$ & $17.28 \pm 26.27$ & $0.002 *$ \\
\hline VAS-activity (mm) & $84.78 \pm 10.25$ & $26.64 \pm 15.13$ & $0.001 *$ \\
\hline VAS night (mm) & $68.07 \pm 26.11$ & $21.78 \pm 17.10$ & $0.002^{*}$ \\
\hline DASH score & $55.90 \pm 13.79$ & $23.34 \pm 15.34$ & $0.001 *$ \\
\hline \multicolumn{4}{|l|}{ McConnell Taping Group } \\
\hline VAS-rest (mm) & $29.84 \pm 30.60$ & $10.00 \pm 17.19$ & $0.009 *$ \\
\hline VAS-activity (mm) & $59.15 \pm 23.65$ & $14.15 \pm 17.64$ & $0.002 *$ \\
\hline VAS night (mm) & $58.92 \pm 28.94$ & $12.30 \pm 17.06$ & $0.002 *$ \\
\hline DASH score & $38.89 \pm 16.55$ & $11.15 \pm 10.22$ & $0.001 *$ \\
\hline \multicolumn{4}{|l|}{ Manual Therapy Group } \\
\hline VAS-rest (mm) & $23.32 \pm 21.20$ & $4.50 \pm 11.33^{*}$ & $0.003^{*}$ \\
\hline VAS-activity (mm) & $58.85 \pm 24.55$ & $12.50 \pm 15.16$ & $0.001^{*}$ \\
\hline VAS night (mm) & $57.00 \pm 31.34$ & $10.78 \pm 15.59$ & $0.002 *$ \\
\hline DASH score & $47.28 \pm 16.53$ & $17.14 \pm 9.99$ & $0.001^{*}$ \\
\hline \multicolumn{4}{|l|}{ Control Group } \\
\hline VAS-rest (mm) & $29.91 \pm 32.28$ & $18.98 \pm 23.82$ & $0.122 *$ \\
\hline VAS-activity (mm) & $69.92 \pm 17.83$ & $48.14 \pm 18.22$ & $0.001^{*}$ \\
\hline VAS night (mm) & $61.14 \pm 23.84$ & $44.64 \pm 26.13$ & $0.008^{*}$ \\
\hline DASH score & $55.53 \pm 24.95$ & $52.86 \pm 22.79$ & $0.012^{*}$ \\
\hline
\end{tabular}

${ }^{*} \mathrm{p}<0.05$. Pre: Before treatment. Post: After treatment. VAS: Visual Analog Scale. DASH: Disabilities of the Arm, Shoulder, and Hand Questionnaire. 
Table 3: Changes in rest, activity, night time pain intensity and functional activity levels between treatment groups after treatment evaluation.

\begin{tabular}{lccccc}
\hline & & VAS rest $(\mathrm{mm})$ & VAS activity $(\mathrm{mm})$ & VAS night $(\mathrm{mm})$ & \multicolumn{2}{c}{ DASH (score) } \\
& & $\mathrm{p}$ & $\mathrm{p}$ & $\mathrm{p}$ & $\mathrm{p}$ \\
\hline KT and MC & Post Pre & 0.214 & 0.126 & 0.789 & 0.423 \\
KT and MT & Post Pre & 0.299 & 0.232 & 0.854 & 0.476 \\
MC and MT & Post Pre & 0.788 & 1.000 & 0.981 & 0.808 \\
\hline
\end{tabular}

KT: Kinesio Taping Group. MC: McConnell Taping Group. MT: Manual Therapy Group. Pre: Before treatment. Post: After treatment. VAS: Visual Analog Scale. DASH: Disabilities of the Arm, Shoulder, and Hand Questionnaire.

in terms of pain and functionality parameters.

Although there are many studies in the literature showing that manual treatment is effective, the results of studies on taping treatment are contradictory. There are also studies showing that different taping methods do not provide additional benefits and cannot be an alternative to conventional physiotherapy. ${ }^{16}$

Kaya et al. ${ }^{17}$ applied manual therapy together with exercises to a group and KT together with exercises to another group in cases diagnosed with SIS for six weeks and reported that improvement was ensured in pain and disability in both groups, and no statistically significant difference was found between the two groups.

Kul et al. ${ }^{18}$ applied a home program and Kinesio band to one group, and a conventional physiotherapy and home exercise program to the other group. The authors reported that the physiotherapy program was more effective and that the KT application should not be considered as an alternative treatment method for SIS, but rather it could be implemented as a supportive treatment.

Frazier et al. ${ }^{19}$ applied KT together with physiotherapy to cases diagnosed with one of the following (shoulder pain, RM rupture, SIS, and acromioplasty) in the case series and reported as a result of the study that there were significant improvements in pain, function, and disability parameters and that KT could be a helpful treatment for a comprehensive physiotherapy program.

Senbursa et al. ${ }^{10}$ applied manual therapy (joint and soft tissue mobilization techniques) to a group and a "self-training" program to another group, and they achieved an earlier reduction in pain and earlier recovery in strength and function in the manual therapy group when compared to the exercise group.

In another study conducted, seven articles that were appropriate for the study among 1214 potential studies conducted between 1996 and 2009 were reviewed to examine the effectiveness of manual therapy in painful shoulders. As a result, it was reported that manual therapy was an efficient method for reducing pain and increasing function and mobility. ${ }^{20}$

In our study, when $\mathrm{KT}, \mathrm{MC}$, and MT were added to the conventional physiotherapy program, it was observed to further reduce pain and further improve function. The reason for a significant difference in the change of the pain parameter during the post-treatment activity may be due to the elimination of stress on the glenohumeral joint. ${ }^{21}$

In a study, it was reported that KT applied to the anterior and posterior parts of the supraspinatus and deltoid muscle in healthy individuals increased the subacromial space. ${ }^{22}$

In shoulder problems, scapular mobilization and glenohumeral joint mobilization techniques are effectively used for opening adherence and increasing joint mobility. ${ }^{20}$ The soft tissue and joint mobilization methods applied in the study were preferred due to these effects.

The reason for this can be the fact that since the reduction of stress on the glenohumeral joint and the depression of the acromioclavicular joint elevation increase the mobility of the scapula, it reduces pain sensitivity by the sensorimotor and proprioceptive feedback mechanism in shoulder impingement syndrome. ${ }^{23}$

Shaheen et al. ${ }^{24}$ investigated the effect of rigid taping and KT on the scapular kinematics and pain in SIS and stated that both tapings 
had positive effects on the scapular kinematics and pain on the sagittal plane, but had no effect on pain on the scapular plane.

It is frequently emphasized in the literature that the weakness of the scapulothoracic muscles and the muscle strength difference, the inadequate control of glenohumeral and scapulothoracic movements during shoulder elevation are important factors for the formation of SIS and that the exercise program takes an important place in SIS rehabilitation, although it has not been proven to be the most effective exercise program for the shoulder. ${ }^{25,26}$ Therefore, the same exercise program, including capsule stretching exercises, posture exercises, and strengthening exercises for the scapulothoracic and shoulder peripheral muscles with elastic tapes, was applied to all groups. In a systematic review investigating the effectiveness of manual therapy in musculoskeletal disorders of the shoulder, the methods of manual therapy were reported to be more effective upon comparing them with the exercise or conventional physiotherapy methods. ${ }^{27}$

The DASH is frequently used to determine the quality of life and the functionality of a patient in daily life. In their study, Shakeri et al. ${ }^{28}$ evaluated the functional level by the DASH in patients diagnosed with shoulder impingement syndrome. KT was applied to the first group, and placebo taping was applied to the other group. The researchers performed the re-evaluation one week after the taping and demonstrated that there was a more significant functional improvement in the treatment group.

In a study conducted by Senbursa et al., ${ }^{29}$ patients diagnosed with supraspinatus tendinitis were divided into three groups (supervised exercise program (Group 1), a supervised exercise program combined with joint and soft tissue mobilization (Group 2), and a home-based rehabilitation program (Group 3)). A decrease in pain, an increase in the muscle strength, and improvement in the functional level were observed in all groups, and there was no difference between the groups in terms of the parameters evaluated, but the functional improvement was the highest in the manual therapy group. Moreover, it was noted that manual therapy could be preferred primarily due to reasons such as the elimination of pain and an increase in the joint range of motion in patients in the short term.

In our study, it was found that there was a significant improvement in DASH scores in all treatment groups when compared with the control group. No significant differences were detected between the treatment groups. Similarly, to the literature, all the treatment methods applied were observed to improve the daily life activities of cases diagnosed with SIS. ${ }^{11,17,18}$

Despite a small number in the literature, there are studies showing that manual techniques have been compared with physiotherapy or exercise programs in shoulder problems. However, no study comparing these three techniques with each other has been encountered. In the present study, it was determined that all three programs positively affected the patients' levels of functional activity and did not have superiorities over each other.

The functional recovery of the groups, which was assessed by the DASH, was similar. The implication of this finding might be that the reduction in pain, especially during an activity, may be permitted to the more effective delivery of exercise and the function recovery for both groups. It may be highlighted that exercise may have a dominant effect.

\section{Limitations}

In this study, the techniques applied in the manual therapy group were selected according to the needs of the patient. This may have caused heterogeneity. The patients included were collected from single hospital. They may have specific demographic and clinical features which might limit the generalization of the outcomes. Another area of concern is that in this study, the pain intensity and functionality were assessed before and after treatment as outcome measures.

According to published data summaries of research focusing on management of shoulder pain, it looks like that taping is not sufficient to treat shoulder impingement syndrome and it is compulsory to combine with other remedies to get the best results. Future study might be suggested to assess the long-term effects of treatment on pain intensity and functionality.

The outcomes of current study might be implicated that each of this outcome measure represented only one particular feature of 
clinical entity. To effectively treat a patient with SIS, the interventions require addressing the multiple aspects of the presenting clinical issues.

\section{Conclusion}

The most important point that differentiates the present study from other studies in the literature is that, unlike physiotherapy and rehabilitation programs, different taping methods and manual therapy were applied with the exercise program along with physical therapy. KT and/or MC, manual therapy might be prescribed for patients with SIS, especially when pain relief is the shortterm goal of the treatment. More clinical research is needed to investigate the effect of KT or MC on scapular and shoulder kinematics and on the disability of the arm and shoulder.

\section{Acknowledgement: None.}

Authors' Contributions: SAA: Literature search, data collecting, data analysis, writing; FE: Study design, critical review; EY: Providing subjects, providing of equipments; GB: study design, critical review.

\section{Conflict of Interest: None}

Funding: None.

Ethical Approval: The protocol of the present study was approved by the Non-Interventional Research Ethics Committee of Hacettepe University (issue: LUT 12/89-33 date: 26.07.2012).

\section{REFERENCES}

1. Takeno K, Glaviano NR, Norte GE, et al. Therapeutic Interventions for Scapular Kinematics and Disability in Patients With Subacromial Impingement: A Systematic Review. J Athl Train. 2019;54:283-295.

2. Garofalo R, Karlsson J, Nordenson U, et al. Anterior-superior internal impingement of the shoulder: an evidence-based review. Knee Surg Sports Traumatol Arthrosc. 2010;18:1688-1693.

3. Mottram S. Dynamic stability of the scapula. Man ther. 1997;2:123-131.

4. Halseth T, McChesney JW, DeBeliso M, et al. The effects of kinesio ${ }^{\mathrm{TM}}$ taping on proprioception at the ankle. J Sport Sci Med. 2004;3:1-7.
5. Ackermann B, Adams R, Marshall E. The effect of scapula taping on electromyographic activity and musical performance in professional violinists. Aust J Physiother. 2002;48:197-203.

6. Kalichman L, Vered E, Volchek L. Relieving symptoms of meralgia paresthetica using Kinesio taping: a pilot study. Arch Phys Med Rehabil. 2010;91:1137-1139.

7. Kachingwe AF, Phillips B, Sletten E, et al. Comparison of manual therapy techniques with therapeutic exercise in the treatment of shoulder impingement: a randomized controlled pilot clinical trial. JJ Man Manip Ther. 2008;16:238-247.

8. Williams Jr JW, Holleman Jr DR, Simel D. Measuring shoulder function with the Shoulder Pain and Disability Index. J Rheumatol. 1995;22:727-732

9. Yemul SR. Comparison of supervised exercise with and without manual physical therapy for patients with shoulder impingement syndrome. Int J Curr Res Rev. 2013;5:144-149.

10. Senbursa G, Baltacı G, Atay A. Comparison of conservative treatment with and without manual physical therapy for patients with shoulder impingement syndrome: a prospective, randomized clinical trial. Knee Surg Sports Traumatol Arthrosc. 2007;15:915-921.

11. Kaya E, Zinnuroglu M, Tugcu I. Kinesio taping compared to physical therapy modalities for the treatment of shoulder impingement syndrome. Clin Rheumatol. 2011;30:201-207.

12. Cools A, Witvrouw E, Danneels L, et al. Does taping influence electromyographic muscle activity in the scapular rotators in healthy shoulders? Man ther. 2002;7:154162.

13. Lederman E. Fundamentals of manual therapy: physiology, neurology, and psychology. Churchill Livingstone; 1997.

14. Kase K, Wallis J, Kase T. Clinical therapeutic applications of the Kinesio taping. USA: Kinesio. 2013.

15. Macdonald R. Taping techniques: principles and practice. Butterworth-Heinemann Medical; 2004.

16. Kocyigit F, Acar M, Turkmen MB, et al. Kinesio taping or just taping in shoulder subacromial impingement syndrome? A randomized, doubleblind, placebo-controlled trial. Physiother Theory Pract. 2016;32:501-508.

17. Kaya DO, Baltaci G, Toprak U, et al. The clinical and sonographic effects of kinesiotaping and exercise in comparison with manual therapy and exercise for patients with subacromial impingement syndrome: a preliminary trial. J Manipulative Physiol Ther. 2014;37:422-432

18. Kul A, Ugur M. Comparison of the efficacy of conventional physical therapy modalities and 
kinesio taping treatments in shoulder impingement syndrome. Eurasian J Med. 2019;51:139-144.

19. Frazier S, Whitman J, Smith M. Utilization of kinesio tex tape in patients with shoulder pain or dysfunction: a case series. Advanced Healing. 2006;24:18-20.

20. Camarinos J, Marinko L. Effectiveness of manual physical therapy for painful shoulder conditions: a systematic review. J Man Manip Ther 2009;17:206-215.

21. Luque-Suarez A, Navarro-Ledesma S, Petocz P, et al. Short term effects of kinesiotaping on acromiohumeral distance in asymptomatic subjects: a randomised controlled trial. Man ther. 2013;18:573-577.

22. Lyman KJ, Gange KN, Hanson TA, et al. Effects of 3 different elastic therapeutic taping methods on the subacromial joint space. J Manipulative Physiol Ther. 2017;40:494-500.

23. Bang MD, Deyle GD. Comparison of supervised exercise with and without manual physical therapy for patients with shoulder impingement syndrome. J Orthop Sports Phys Ther. 2000;30:126-137.

24. Shaheen AF, Bull AM, Alexander CM. Rigid and elastic taping changes scapular kinematics and pain in subjects with shoulder impingement syndrome; an experimental study. J Electromyogr Kinesiol. 2015;25:84-92.

25. Struyf F, Nijs J, Mollekens S, et al. Scapularfocused treatment in patients with shoulder impingement syndrome: a randomized clinical trial. Clin Rheumatol. 2013;32:73-85.

26. Park S-I, Choi Y-K, Lee J-H, et al. Effects of shoulder stabilization exercise on pain and functional recovery of shoulder impingement syndrome patients. $J$ Phys Ther Sci. 2013;25:1359-1362.

27. Ho C-YC, Sole G, Munn J. The effectiveness of manual therapy in the management of musculoskeletal disorders of the shoulder: a systematic review. Man ther. 2009;14:463-474.

28. Shakeri H, Keshavarz R, Arab AM, et al. Therapeutic effect of kinesio-taping on disability of arm, shoulder, and hand in patients with subacromial impingement syndrome: a randomized clinical trial. J Nov Physiother. 2013;3:1-5

29. Senbursa G, Baltaci G, Atay OA. The effectiveness of manual therapy in supraspinatus tendinopathy. Acta Orthop Traumatol Turc. 2010;45:162-167. 